\title{
Insights to Argumentativeness in Relation to Leadership Style and Job Satisfaction: Using Employees' Sport Organizations as an Illustration
}

\author{
Alexandra Bekiari, Varvara Ntakou \\ Faculty of Physical Education and Sports Science, University of Thessaly, Thessaly, Greece \\ Email: sandrab@pe.uth.gr
}

How to cite this paper: Bekiari, A., \& Ntakou, V. (2018). Insights to Argumentativeness in Relation to Leadership Style and Job Satisfaction: Using Employees' Sport Organizations as an Illustration. Open Journal of Leadership, 7, 1-18. https://doi.org/10.4236/ojl.2018.71001

Received: January 9, 2018

Accepted: February 24, 2018

Published: February 27, 2018

Copyright ( 2018 by authors and Scientific Research Publishing Inc. This work is licensed under the Creative Commons Attribution International License (CC BY 4.0).

http://creativecommons.org/licenses/by/4.0/

(c) (i) Open Access

\begin{abstract}
Aim of the study is to: a) reveal statistically significant differences in argumentativeness, leadership style and employee satisfaction between gender and age, b) explore the relationship between perceived superiors' argumentativeness, leadership style and self-reported employees' job satisfaction, c) investigate the influence of argumentativeness on leadership style and employee satisfaction in sport organizations and d) propose an employees' and superiors' typology. The sample consisted of 211 Greek employees of sport organizations. According to MANOVA's findings, statistically significant differences were observed between gender and age in perceived superiors' argumentativeness, leadership style and self-reported employee satisfaction. Perceived superiors' argumentativeness was negatively related to autocratic leadership style, self-reported employees' salary and promotion. There was a positive significant relationship between superiors' argumentativeness and democratic leadership style, employees' work conditions, work content, immediate superior and organization as a whole. Regression analysis revealed that perceived superiors' argumentativeness could significantly predict the variables of democratic leadership style and employees' work conditions, work content and immediate superior. Distinct types of relations between employees and superiors are the "unitarist" and the "individualist".
\end{abstract}

\section{Keywords}

Argumentativeness, Leadership Style, Job Satisfaction, Sport Organizations, Employees

\section{Introduction}

This study aims at investigating relations among perceived superiors' argumen- 
tativeness and leadership style and self-reported subordinates' job satisfaction in sport organizations in the Municipalities. The academic added value is expected to lie in the understanding of the relation between argumentativeness, leadership style and job satisfaction. The practical added value is supposed to consist in detecting particular parameters which are significant for effective practical choices in the relations and function within such organizations.

In particular, this study intends to answer the following research questions:

- Are there any differences between gender and age regarding argumentativeness, leadership style and job satisfaction?

- Is there a positive or negative relationship between perceived superiors' argumentativeness, leadership style and employees' self-reports of job satisfaction in sport organizations?

- To what extent the argumentativeness could be a significant predictor of leadership style and job satisfaction?

- Can superiors' and employees' typology regarding parameters of argumentativeness, leadership style and job satisfaction is extracted?

\section{Literature Review}

\subsection{Argumentativeness}

It has been argued that the instructors' communication with their trainees has a noticeable effect on the learning process as well as a significant interaction with possible aggressiveness (Bekiari, 2012; 2017b; Bekiari, Deliligka, \& Hasanagas, 2017; Bekiari, Deliligka, \& Koustelios, 2016; Bekiari, Digelidis, \& Sakellariou, 2006; Bekiari \& Hasanagas, 2015; 2016a,b,c; Bekiari, Hasanagas, Theoharis, Kefalas, \& Vasilou, 2015; Bekiari, Kokaridas, \& Sakellariou, 2005; 2006; Bekiari, Patsiaouras, Kokaridas, \& Sakellariou, 2006; Bekiari, Koustelios, \& Sakellariou, 2000; Bekiari, Nikolaidou, \& Hasanagas, 2017; Bekiari \& Pachi, 2017; Bekiari, Pachi, \& Hasanagas, 2017; Bekiari \& Sakellariou, 2003; Bekiari \& Spanou, 2018; Bekiari \& Syrmpas, 2015; Hasanagas \& Bekiari, 2015; 2017; Hasanagas, Bekiari, \& Vasilos, 2017; Manoli \& Bekiari, 2015; Myers \& Claus, 2012; Theoharis \& Bekiari, 2017; Theoharis, Bekiari, \& Koustelios, 2017). Argumentativeness is considered to be a cognitive skill which is necessary for a thinking person and thus for our contemporary culture (Kuhn \& Crowell, 2011; Osborne, 2010) impacting positively in human communication (Goodboy \& Myers, 2012). It is the predisposition of the individual to support his positions on controversial issues refuting verbally the views of respondents in relation to specific issues (Infante $\&$ Rancer, 1996). It targets to the views of respondents on a subject constituting a constructive feature of human communication (Infante, 1987; Infante \& Rancer, 1996; Rancer \& Avtgis, 2006). Argumentativeness has been studied in various communication environments, such as family (Snyder, 1993), in teenage relationships (Edwards \& Myers, 2007; Myers \& Knox, 2000; Myers \& Rocca, 2000; 2001; Rancer, Avtgis, Kosberg, \& Whitecap, 2000; Tremblay, 2000), interpersonal relationships (Avtgis \& Rancer, 1997; Bayer \& Cegala, 1992; Infante \& 
Gorden, 1989). Argumentativeness increases the attainment of personal goals (Infante, 1981; Infante \& Rancer, 1996), improves interpersonal relationships by encouraging better solutions to conflicts (Rancer \& Infante, 1985), is linked to positively to emotional learning, motivation, attraction and satisfaction (Edwards \& Myers, 2007; Myers, 2002; Myers \& Knox, 2000; Myers \& Rocca, 2000; 2001; Rancer \& Avtgis, 2006; Schrodt, 2003; Syrmpas \& Bekiari 2015). Additionally, the ability of individuals to argue is an important factor in their effectiveness (Kline, 1998) and is considered a delightful activity that makes people more reliable, eloquent, creative and socially acceptable (Rancer, Kosberg, \& Bauks, 1992). Based on the principle of reciprocity (Gouldner, 1960), it appears that when the superior attempts to persuade with arguments in order to support his position on a controversial issue, it is very likely that his subordinates will have a positive image about him. The superiors who uses arguments are considered to be loved by their subordinates (Gorden, Infante, \& Graham, 1988) attract naturally social and scientifically the learners (Syrmpas \& Bekiari, 2015), affecting positively the satisfaction and empathy (Myers \& Knox, 2000).

\subsection{Leadership Style}

The supervisor can significantly influence the motivation and the collaborative spirit of employees as well as the general climate of the organizational culture and functioning. Leader behaviour plays a key role in team cohesion (Murray, 2006). According to Burroughs (2005), leadership is the process of influencing the attitudes and behaviours of a group of people, formal or informal, small or large, by one person (leader) in order them to work willingly and cooperatively achieving the goals of the organization with maximum efficiency. According to Storey (2005), leadership is the balancing of particularly high abilities in a person who is innovative, experimenting and reinforcing group cohesion by providing information to its members, conceding to them power and recognizing their job offer. Chelladurai and his associates (Chelladurai, 1978; 1990; Chelladurai \& Carron, 1983) proposed the Multidimensional Leadership Model, which consists of five leadership styles: democratic, authoritarian, mentoring, social support and positive feedback. According to this model, the convergence of the three types of leadership (indicative, preferred, perceived) affects positively to the team's mood improving the performance and the job satisfaction of its members. Study has shown that the most effective leadership style is the democratic one in which the leader-supervisor distributes as much power to his subordinates as (Schmuck, 1968), while unwanted leadership is considered the authoritarian (Surujlal, \& Dhurup, 2012). In addition, three attributes of an effective leader were recorded: development of interpersonal relationships, division of competences and decision-making (Bennie \& O'Connor, 2012), with socially supportive leadership style to stimulate team morale (Bray, Millen, Eidsness, \& Leuzinger, 2005; Hampson \& Jowett, 2014) and reinforce their desire to participate in physical activities outside of work (Chatzisarantis \& Hagger, 2009). Training and 
instruction style is associated negatively with stress (Monemi \& Moghaddam, 2013), while the authoritarian style is associated positively with anxiety and the use of verbal aggressive behaviour by the leader (Bekiari, 2014). Conclusively, the supervisors with their behaviour and the way that they perform their tasks affect the job satisfaction of the subordinates, promoting the production and implementation of innovative ideas within the enterprise (DeJong \& DenHartog, 2007).

\subsection{Job Satisfaction}

Job satisfaction is defined as the worker's assessment of the job and the framework in which it is performed (Weiss \& Cropanzano, 1996), which is not a stable situation but it is likely to change because it is determined by various factors (Robbins \& Judge, 2013) such as the specific characteristics of the profession, the conditions in which the profession is applied, characteristics of the employees personality with the natural consequence that employees (Robbins \& Judge, 2013) do not getting absolute satisfaction from their profession. In order the job satisfaction to be measured various factors must be taken into consideration such as the person's subjective view of how much he desires what he derives from his work (Vroom, 1964), his value system (Locke, 1999), the framework and the context of job. In addition, positive or negative attitudes towards work can have a significant impact on many forms of organizational behavior (Koustelios, 2001) and is related to the individual's professional experience (Koustelios \& Kousteliou, 2001). Job satisfaction encourages employees to make a greater contribution to the production process, as it has a positive influence on the quality of the provided services (Chang \& Chelladurai, 1997), increases the productivity and establishes a good cooperative behavior in the workplace (Lussier, Say, \& Corman, 1999) as employees learn more easily their new tasks and make fewer complaints (Luthans, Norman, \& Hughes, 2006). In addition, job satisfaction is negatively linked to increased absenteeism of employees from the workplace (Tsiggilis, Koustelios, \& Togia, 2004), reducing the phenomenon of inappropriate access to it and the frequency of accidents (Luthans, Norman, \& Hughes, 2006) and is associated with low labor mobility indicators (Hatton et al., 2001; Tsiggilis et al., 2004). Smith \& Bourke (1992) recorded the most important factors of job satisfaction, as follows: a) the nature of the work itself, b) the salary, c) the possibility of promotions, d) the colleagues, and e) the superiors. For example, research carried out on employees of cultural structures showed that employees were satisfied with their supervisor and the nature of their work but were dissatisfied with their salary (Koustelios, Theodorakis, \& Goulimaris, 2004).

\section{Method}

\subsection{Participants and Procedures}

The sample of the study consisted of 211 employees ( 88 males, 123 females) aged 22 - 65 years old $(\mathrm{M}=42.8, \mathrm{SD}=0.89)$ of sport organizations in the Municipali- 
ties of Trikala, Larissa and Karditsa regions from Local Authorities of Grade A and B (Grade A = Municipalities, Grade B = Prefectures of Thessaly, Greece). It was selected randomly on the basis of employees list. The participants were 22 35 years old (17 employees), 36 - 45 years old (53 employees), 46 - 55 years old (91 employees) and 56 - 65 years old (50 employees). Participants of different socio-economic status were included. All employees answered the questionnaires about perceived superiors' argumentativeness and leadership style and self-reported employees' job satisfaction in sport organizations. The questionnaires were answered voluntarily within approx. $25 \mathrm{~min}$. It was noticed that their anonymity would be observed. Thereby, they were expected to give sincere answers. Rules of research ethics and best practice were also observed.

\subsection{Instruments}

Argumentativeness. The Greek version (Syrmpas \& Bekiari, 2015) was used to assess perceived superiors' argumentativeness, based on the conceptualization of Myers \& Rocca (2000). Preliminary examination (Syrmpas \& Bekiari, 2015) supported the psychometric properties of the instrument. In particular, confirmatory factor analysis indicated satisfactory fit indices (CFI: 0.98, SRMR: 0.05), and internal consistency of the scale $(\alpha=0.87)$. The scale consisted of ten items (e.g., "enjoys a good discussion with arguments on a controversial subject with employees", "avoids making use of arguments when he disagrees with employees"). Participants were asked to respond to the items based on a 5-point Likert-type scale ranging from $1=$ never to $5=$ always.

Leadership style. A shorter version of the Leadership Scale for Sports (Chelladurai \& Saleh, 1980), adapted in Greek population (Bekiari, 2014; 2016), was used in order to measure perceived superiors' leadership style. This short version consisted of 6 items describing autocratic leadership (e.g., "decides alone what to do regarding the organization and operation of the work") and 5 items describing democratic leadership style (e.g., "allows employees to set their own goals") only two of the five dimensions were used. Responses were given on a 5-point Likert-type scale ranging from 1: Strongly disagree to 5: Strongly agree.

Job satisfaction: For the measurement of job satisfaction the Employee Satisfaction Inventory-ESI (Koustelios \& Bagiatis, 1997) was used. The inventory was created using Greek employees as a sample. It included 24 items, which measure six dimensions of job satisfaction: Working conditions (5 items), Salary (4 items), Promotions (3 items), Work itself (4 items), Immediate superior (4 items) and the organization as a whole (4 items). The responses were given in a five-level Likert scale ranging from $1=$ strongly disagree to $5=$ strongly agree.

\subsection{Data Analysis}

Data analysis included the use of the Statistical Package for Social Sciences (SPSS 21.0). Cronbach's $\alpha$ reliability analysis was used to examine the internal consistency of the factors of each questionnaire. Afterwards, two-way MANOVA was used in order to examine differences between gender and age in argumentative- 
ness, leadership style and employee satisfaction. The parametric test Pearson was used to measure the correlation between the subscales of the questionnaires. This bivariate test was implemented in order to provide an overview of all possible correlations. Additionally, regression analysis was conducted in order to explore the extent to which the perceived superiors' argumentativeness could be a significant predictor of their leadership style and the employees' job satisfaction. The level of statistical significance was set at 5\%. Finally, employees' and superiors' typology regarding parameters of argumentativeness, leadership style perception and employees' job satisfaction will be formulated using Principal Component Analysis.

\section{Results}

Two-way MANOVA was performed to examine differences existed in argumentativeness, leadership style and employee satisfaction between gender and age. The findings according to Wilks' $\lambda$ showed statistically significant multivariate effect on gender $\lambda=0.76, \mathrm{~F}(9,195)=6.73, p<0.001$, age $\lambda=0.59, \mathrm{~F}(27,570)=$ $4.16, p<0.001$ and the interaction between gender and age, $\lambda=0.60, \mathrm{~F}(27,570)$ $=4.06, p<0.001$.

The examination of the univariate effects revealed significant effect of gender on argumentativeness $\mathrm{F}(1,203)=11.97, p<0.05, \eta^{2}=0.06$, democratic style $\mathrm{F}(1$, 203) $=14.18, p<0.001, \eta^{2}=0.07$, salary $\mathrm{F}(1,203)=4.08, p=0.05, \eta^{2}=0.02$, promotion $\mathrm{F}(1,203)=5.24, p<0.05, \eta^{2}=0.03$, immediate superior $\mathrm{F}(1,203)=$ 4.00, $p=0.05, \eta^{2}=0.02$ and organization $\mathrm{F}(1,203)=9.12, p<0.05, \eta^{2}=0.04$. An examination of the mean scores indicated that men employees proved to have higher score in argumentativeness $(\mathrm{M}=3.53, \mathrm{SD}=1.00)$, democratic style $(\mathrm{M}=$ $3.67, \mathrm{SD}=1.03)$, as well as in immediate superior $(\mathrm{M}=3.68, \mathrm{SD}=0.85)$ compared to women. Whereas, concerning salary $(\mathrm{M}=2.45, \mathrm{SD}=0.72)$, promotion $(\mathrm{M}=2.61, \mathrm{SD}=0.74)$ and organization $(\mathrm{M}=3.11, \mathrm{SD}=0.63)$ women employees presented higher score than men (Table 1 ).

Also, the examination of the univariate effects revealed significant effect of age on work conditions $\mathrm{F}(3,203)=5.85, p<0.05, \eta^{2}=0.08$, salary $\mathrm{F}(3,203)=3.75, p$ $<0.05, \eta^{2}=0.05$ and promotion $\mathrm{F}(3,203)=3.87, p<0.05, \eta^{2}=0.05$. According to pairwise comparison, the examination of the mean scores indicated that employees aged from 46 to 55 presented higher levels $(\mathrm{M}=3.76, \mathrm{SD}=0.67)$ of work conditions, than those who belong to the group of 36-45 years old. Moreover on salary, ages from $36-45$ revealed higher scores $(\mathrm{M}=2.50, \mathrm{SD}=0.82)$ than the group of 22 - 35 years old, as well as employees 46 - 55 years old indicated higher score $(\mathrm{M}=2.51, \mathrm{SD}=0.86)$ compared to $22-35$ years old (Table 2$)$.

Finally, the examination of the univariate effects presented significant effect of the interaction between gender and age on argumentativeness $\mathrm{F}(3,203)=$ 8.64, $p<0.001, \eta^{2}=0.11$, autocratic style $\mathrm{F}(3,203)=3.13, p<0.05, \eta^{2}=0.04$, democratic style $\mathrm{F}(3,203)=7.02, p<0.001, \eta^{2}=0.10$, salary $\mathrm{F}(3,203)=4.61, p$ $<0.05, \eta^{2}=0.06$, promotion $\mathrm{F}(3,203)=3.55, p<0.05, \eta^{2}=0.05$, work content $\mathrm{F}(3,203)=6.85, p<0.001, \eta^{2}=0.09$, immediate superior $\mathrm{F}(3,203)=6.01$, 
Table 1. Gender differences.

\begin{tabular}{|c|c|c|c|c|c|c|}
\hline \multirow[t]{2}{*}{ Variables } & \multicolumn{2}{|c|}{ Men } & \multicolumn{2}{|c|}{ Women } & \multicolumn{2}{|r|}{ Partial } \\
\hline & M & $\mathrm{SD}$ & $\mathrm{M}$ & SD & $p$ & $\eta^{2}$ \\
\hline Argumentativeness & 3.53 & 1.00 & 3.13 & 0.99 & 0.001 & 0.056 \\
\hline Autocratic style & 3.06 & 1.01 & 3.03 & 0.92 & 0.196 & 0.008 \\
\hline Democratic style & 3.67 & 1.03 & 3.23 & 10.01 & 0.000 & 0.065 \\
\hline Work conditions & 3.58 & 0.66 & 3.62 & 0.72 & 0.957 & 0.000 \\
\hline Salary & 2.38 & 0.99 & 2.45 & 0.72 & 0.045 & 0.020 \\
\hline Promotion & 2.30 & 0.73 & 2.61 & 0.74 & 0.023 & 0.025 \\
\hline Work content & 3.74 & 0.70 & 3.92 & 0.74 & 0.883 & 0.000 \\
\hline Immediate superior & 3.68 & 0.85 & 3.54 & 0.88 & 0.047 & 0.019 \\
\hline Organization & 2.95 & 0.59 & 3.11 & 0.63 & 0.003 & 0.043 \\
\hline
\end{tabular}

Table 2. Age differences.

\begin{tabular}{|c|c|c|c|c|c|c|c|c|c|c|}
\hline \multirow{2}{*}{ Variables } & \multicolumn{2}{|c|}{$22-35$} & \multicolumn{2}{|c|}{$36-45$} & \multicolumn{2}{|c|}{$46-55$} & \multicolumn{2}{|c|}{$56-65$} & \multirow[b]{2}{*}{$p$} & Partial \\
\hline & M & $\mathrm{SD}$ & M & SD & M & $\mathrm{SD}$ & M & SD & & $\eta^{2}$ \\
\hline Argumentativeness & 3.79 & 0.72 & 3.18 & 1.06 & 3.22 & 0.99 & 3.39 & 1.04 & 0.098 & 0.030 \\
\hline Autocratic style & 2.71 & 0.67 & 3.15 & 0.87 & 3.05 & 10.01 & 3.04 & 1.03 & 0.489 & 0.012 \\
\hline Democratic style & 3.96 & 0.75 & 3.31 & 1.08 & 3.32 & 10.01 & 3.51 & 1.09 & 0.073 & 0.034 \\
\hline Work conditions & 3.44 & 0.84 & 3.30 & 0.61 & 3.76 & 0.67 & 3.70 & 0.67 & 0.001 & 0.080 \\
\hline Salary & 1.68 & 0.93 & 2.50 & 0.82 & 2.51 & 0.86 & 2.42 & 0.70 & 0.012 & 0.052 \\
\hline Promotion & 2.18 & 0.66 & 2.57 & 0.76 & 2.31 & 0.67 & 2.81 & 0.80 & 0.010 & 0.054 \\
\hline Work content & 3.85 & 0.73 & 3.71 & 0.82 & 3.79 & 0.73 & 4.08 & 0.56 & 0.161 & 0.025 \\
\hline Immediate superior & 4.00 & 0.72 & 3.66 & 0.79 & 3.50 & 0.89 & 3.59 & 0.93 & 0.128 & 0.028 \\
\hline Organization & 3.13 & 0.73 & 3.05 & 0.63 & 3.02 & 0.54 & 3.04 & 0.72 & 0.587 & 0.009 \\
\hline
\end{tabular}

$p<0.05, \eta^{2}=0.08$ and organization $\mathrm{F}(3,203)=4.88, p<0.05, \eta^{2}=0.07$. According to pairwise comparison, the examination of the mean scores on argumentativeness $(M=4.15, \mathrm{SD}=0.51)$, democratic style $(\mathrm{M}=4.26, \mathrm{SD}=0.54)$ and immediate superior $(\mathrm{M}=4.24, \mathrm{SD}=0.45)$ higher scores revealed men in age group $36-45$, than women in that group. As far as salary and organization are concerned, higher scores were presented by women $(\mathrm{M}=2.50, \mathrm{SD}=0.94$ and $\mathrm{M}$ $=3.82, \mathrm{SD}=0.31)$ in ages from 22 to 35 years old than men in those ages. Moreover, men aged from 46 - 55 years old showed higher scores $(M=3.25$, SD $=1.10$ ) in autocratic style, compared to women at that ages. Furthermore, women from age groups 22 - 35 and 36 - 45 years old revealed higher score on promotion than men. Finally concerning work content, men aged from 36 to 45 years old revealed higher score $(\mathrm{M}=4.03, \mathrm{SD}=0.44)$ than women at this group of ages, while women from 46 to 55 years old presented higher score $(\mathrm{M}=4.11$, $\mathrm{SD}=0.50)$ than men at these ages. 
In addition, a correlation analysis was conducted, the results of which are presented in Table 3. As it can be seen, there was a negative significant relationship between perceived superiors' argumentativeness and autocratic leadership style $(r=-0.69)$, self-reported employees' salary $(r=-0.32)$ and promotion $(r=-0.15)$, while there was a positive significant relationship between superiors' argumentativeness and democratic leadership style $(r=0.97)$, employees' work conditions $(r=0.59)$, work content $(r=0.54)$, immediate superior $(r=0.74)$ and organization $(r=0.31)$. At the same time, Table 3 presents the Cronbach's alpha, mean scores and standard deviations of the variables.

Moreover, a series of simple regression analyses were conducted to examine the extent to which perceived superiors' leadership style and self-reported employees' job satisfaction could be predicted from the ratings of superiors' argumentativeness. The results indicated that perceived argumentativeness could predict significant variance in leadership style $(\mathrm{F}(2,208)=2477.99, p<0.001)$ with an R2 of $96 \%$. Perceived argumentativeness explained $92.1 \%$ of the variance in democratic leadership style $\left(\beta=1.01, \mathrm{t}_{(206)}=49.41, p<0.001\right)$. Another linear regression analysis was conducted to predict employees' job satisfaction based on superior argumentativeness. The results indicated that perceived superior argumentativeness could predict significant variance in job satisfaction $\left(\mathrm{F}_{(6,204)}=\right.$ 63.73, $p<0.001$ ) with an R2 of $65.2 \%$. Argumentativeness explained $7.1 \%$ of the variance in work conditions $\left(\beta=0.30, \mathrm{t}_{(198)}=3.95, p<0.001\right), 10.2 \%$ of the variance in work content $\left(\beta=0.35, \mathrm{t}_{(198)}=4.83, p<0.001\right)$ and $33.5 \%$ of the variance in immediate superior $\left(\beta=0.67, \mathrm{t}_{(198)}=10.15, p<0.001\right)$. The results of the regression analyses are presented in Table 4 .

In the Table 5 two types of relations between employees and superiors are revealed: the "unitarist" and the "individualist" depending on the non-profit- or profit-orientation as employees and on the perception of legitimate attributes of the superior.

Table 3. Reliabilities, means, standard deviations and Pearson correlations among variables.

\begin{tabular}{|c|c|c|c|c|c|c|c|c|c|c|c|c|}
\hline & A & M & $\mathrm{SD}$ & 1 & 2 & 3 & 4 & 5 & 6 & 7 & 8 & 9 \\
\hline 1) Argumentativeness & 0.91 & 3.29 & 1.01 & 1.00 & & & & & & & & \\
\hline 2) Autocratic style & 0.89 & 3.04 & 0.96 & $-0.69^{* *}$ & 1.00 & & & & & & & \\
\hline 3) Democratic style & 0.93 & 3.41 & 1.04 & $0.97^{* *}$ & $-0.73^{\star *}$ & 1.00 & & & & & & \\
\hline 4) Work conditions & 0.76 & 3.60 & 0.69 & $0.59^{* *}$ & $-0.57^{\star *}$ & $0.58^{\star *}$ & 1.00 & & & & & \\
\hline 5) Salary & 0.74 & 2.42 & 0.84 & $-0.32^{\star *}$ & $0.42^{* *}$ & $-0.35^{\star *}$ & $-0.29^{* *}$ & 1.00 & & & & \\
\hline 6) Promotion & 0.64 & 2.48 & 0.75 & $-0.15^{\star}$ & 0.05 & -0.13 & $-0.20^{\star *}$ & $0.26^{* *}$ & 1.00 & & & \\
\hline 7) Work content & 0.82 & 3.84 & 0.73 & $0.54^{* *}$ & $-0.48^{\star *}$ & $0.55^{* *}$ & $0.47^{\star \star}$ & $-0.47^{\star *}$ & $-0.22^{\star \star}$ & 1.00 & & \\
\hline 8) Immediate superior & 0.86 & 3.60 & 0.87 & $0.74^{\star *}$ & $-0.76^{\star *}$ & $0.74^{\star *}$ & $0.52^{\star \star}$ & $-0.31^{\star *}$ & -0.06 & $0.39^{* *}$ & 1.00 & \\
\hline 9) Organization & 0.46 & 3.04 & 0.62 & $0.31^{* *}$ & $-0.29^{* *}$ & $0.29^{* *}$ & $0.22^{\star *}$ & $0.16^{*}$ & $0.15^{\star}$ & $0.19^{\star *}$ & $0.47^{\star *}$ & 1.00 \\
\hline
\end{tabular}

${ }^{* *} p<0.001,{ }^{*} p<0.05, \alpha=$ Cronbach's alpha 
Table 4. Regression analysis results according to argumentativeness.

\begin{tabular}{cccccc}
\hline & B & $95 \%$ CI B & SE & $\beta$ & t \\
\hline Democratic style & 1.01 & $0.94,1.02$ & 0.02 & 0.98 & $49.41^{* *}$ \\
Work conditions & 0.21 & $0.15,0.45$ & 0.08 & 0.30 & $3.95^{* *}$ \\
Work content & 0.25 & $0.21,0.50$ & 0.07 & 0.35 & $4.83^{* *}$ \\
Immediate superior & 0.58 & $0.54,0.80$ & 0.07 & 0.67 & $10.15^{* *}$ \\
\hline
\end{tabular}

${ }^{* *} p<0.001,{ }^{*} p<0.05$.

Table 5. Mixed typology of perceived superior image and employee job satisfaction.

\begin{tabular}{cccc}
\hline & & Unitarist & Individualist \\
\hline \multirow{2}{*}{ Attributes of superior perceived by employees } & Argumentativeness & 0.910 & 0.076 \\
& Autocratic leadership style & -0.852 & -0.075 \\
Attributes of employees according to & Democratic leadership style & 0.917 & 0.064 \\
self-assessment & Work conditions & 0.732 & -0.068 \\
& Salary & -0.496 & 0.609 \\
0.659 & -0.203 & -0.278 \\
\hline
\end{tabular}

Extraction Method: Principal Component Analysis, 2 components extracted.

\section{Discussion}

The goal of the present study was fourfold: a) revealing statistical significant differences between gender and age, b) exploring the relationship between perceived superiors' argumentativeness, leadership style and self-reported employees' job satisfaction, c) investigating the influence of argumentativeness on leadership style and employee satisfaction in sport organizations and d) proposing an employees' and superiors' typology. According to the results of the study, statistically significant differences were observed between gender and age in perceived superiors' argumentativeness, leadership style and self-reported employee satisfaction. Moreover, perceived superiors' argumentativeness was negatively related to autocratic leadership style, self-reported employees' salary and promotion, while there was a positive significant relationship between superiors' argumentativeness and democratic leadership style, employees' work conditions, work content, immediate superior and organization. Furthermore, superiors' argumentativeness could significantly predict the variables of democratic leadership style and employees' work conditions, work content and immediate superior. Distinct types of relations between employees and superiors may be distinguished: "unitarist" and the "individualist".

According to the results of this study, male employees proved to have higher score in argumentativeness, democratic style as well as in leader satisfaction compared to women, whereas, women employees presented higher score than 
men concerning salary, promotion and organism. This can be attributed to the difference between gender-related value systems. The male employees focus on issues of dominance and power relations while female ones on parameters of socio-economic status and ordinariness. Furthermore, employees aged from 46 to 55 presented higher levels of work conditions, than those who belong to the group of 36 - 45 years old. Moreover on salary, ages from 36 - 45 revealed higher scores than the group of 22 - 35 years old, as well as employees 46 - 55 years old indicated higher score compared to $22-35$ years old. This can be reasonably attributed to the increased needs appearing in higher age phases (e.g. family expenses).

Regarding the interaction between gender and age, male employees in age group 36 - 45 indicated higher scores in the importance of argumentativeness, democratic style and immediate superior. Male employees from 46 to 55 years old showed higher scores in autocratic style, compared to female at that age class. This can be explained by the finalization of the opinion and the value system appearing at high age. As far as salary and organization are concerned, female employees presented higher score than male ones in the age group 22 - 35 . Female employees of age groups 22 - 35 and 36 - 45 showed higher score on promotion than men. This is reasonably explained by the market needs (e.g. shopping as life style) appearing in early age phases and by the need of reputation and ordinariness at higher age. Finally, concerning work content, male employees from 36 to 45 years old revealed higher score than women at this age group, while women from 46 to 55 years old presented higher score than men at this age. This indicates that the job satisfaction in case of male employees is mainly based on enthusiasm and dynamism which is a characteristic of earlier age phase. On the other hand, the job satisfaction of women is apparently based on the capability of quick familiarization with the work content which is induced by the experience accumulated with the age.

In the present study, it was supported that the perceived superiors' argumentativeness is negatively related with autocratic leadership style, promotion and self-reported employees' salary. This seems to be in accordance with previous research which indicates that the argumentativeness of instructors is supposed to related with their behavioral parameters such as the friendly and relaxed attitude as well as with the ability to listen comprehensively and carefully (Driver et al., 2000; Myers \& Rocca, 2000). The negative relation of argumentativeness with autocratic leadership style can reasonably be attributed to the fact that superiors who are characterized by authoritarianism often tend to give orders disregarding their employees' views and without justifying their decisions (Barić \& Bucik, 2009; Belias \& Koustelios, 2014), even if these concern salary and opportunity of promotion which are crucial for the job satisfaction.

In the present study, it has also been found that superiors' argumentativeness is positively correlated with employees' work conditions, democratic leadership style, immediate superior, work content and organization. The findings seem to be consistent with the results of previous research, which shows that argumenta- 
tiveness is positively related with the democratic leadership style, supporting active participation of trainees in decision-making and encouraging the respect. It also involves the encouragement by the leader to take initiatives and to freely express ideas (Barić \& Bucik, 2009; Somech, 2005). Apart from that, it also noticeably affect the perception of the importance of work conditions, nature of the work, immediate superiors and organization as a crucial determinants for job satisfaction.

The results of this study appear to be compatible with previous research findings which suggest that argumentativeness helps trainees express themselves and improve their self-confidence and learning (Bekiari, 2012; 2014; Bekiari \& Hasanagas, 2015; Bekiari \& Syrmpas, 2015; Hamilton \& Hample, 2011; Hasanagas \& Bekiari, 2015; Hassandra, Bekiari, \& Sakellariou, 2007; Myers, 2002; Myers \& Rocca, 2001; Syrmpas \& Bekiari, 2015). Further research results suggested that instructors' personality is of importance for their relationship with their trainees and has an effect on their behavior, tactics, emotions or attitudes (Rancer \& Avtgis, 2014). The present study, particularly, revealed that superiors' perceived argumentativeness proved to be the most important indicator of democratic leadership style and the employees' work conditions, the work content and the role of the immediate superior for the job satisfaction. This is in accordance with older results supporting that instructors' argumentativeness is positively related with their responsibility and interpersonal attractiveness as well as with the perceived social fairness (Bekiari, 2017a; Bekiari \& Petanidis, 2016; Bekiari \& Spyropoulou, 2016; Hassandra, Bekiari, \& Sakellariou, 2007; Syrmpas \& Bekiari, 2015), as the employees were satisfied with their supervisor and the nature of their work and dissatisfied only with the salary (Koutselios, Theodorakis, \& Goulimaris, 2004).

Moreover, two types of relations between employees and superiors are revealed: the "unitarist" and the "individualist". The unitarist type disregards salary and promotion perspectives and perceives the sport organization as a whole which ought to function harmonically and ideally (desirable work conditions and content, acceptable leadership and organizational effectiveness). Thus, he perceives himself not as an individualist-oriented entity but as a part of the whole system. Such a type tends to be optimistic and thus to discern quite legitimate dimensions of their superior (argumentativeness and democratic style). Inversely, an employee type who feels such acceptable attributes of the superior, is inspired enough to cultivate unitarist and not individualist values. The individualist type is mainly profit-oriented (salary, promotion). Simultaneously, he is also interested in organizational effectiveness, as this induces a comfortable climate. Such a type is normally not interested in recognizing any particular leadership attributes on their superior, but just in personal profit.

\section{Conclusion}

In conclusion, it could be stated that the superiors' argumentativeness and dem- 
ocratic leadership style either in education (Bekiari, 2016; 2017a; Bekiari \& Balla, 2017; Bekiari \& Manoli, 2016; Bekiari \& Pylarinou, 2017; Deliligka, Bekiari, \& Syrmpas, 2017) or in sports/sport organizations (Donnelly, Carron, \& Chelladurai, 1978; Koustelios, 2001; Koustelios \& Kousteliou, 2001), positively affects the relationship between superior and employee, and not only lead to improvement and job satisfaction, but it could also be destructive for the performance of employees. Future studies could recruit larger number of employees from other organizational contexts of Greece in order to increase findings' generalizability. A relatively more balanced sample in terms of rural-urban interviewees can be collected. Peer influence on motivational climate and on employee satisfaction could also be explored.

\section{Conflicts of Interest}

There are no known conflicts of interest associated with this publication.

\section{References}

Avtgis, T. Ä., \& Rancer, A. S. (1997). Argumentativeness and Verbal Aggressiveness as a Function of Locus of Control. Communication Research Reports, 14, 441-450. https://doi.org/10.1080/08824099709388687

Barić, R., \& Bucik, V. (2009). Motivational Differences in Athletes Trained by Coaches of Different Motivational and Leadership Profiles. Kineziologija, 41, 181-194.

Bayer, C. L., \& Cegala, D. J. (1992). Trait Verbal Aggressiveness and Argumentativeness: Relations with Parenting Style. Western Journal of Communication (Includes Communication Reports), 56, 301-310. https://doi.org/10.1080/10570319209374418

Bekiari, A. (2012). Perceptions of Instructors' Verbal Aggressiveness and Physical Education Students' Affective Learning. Perceptual and Motor Skills, 115, 325-335. https://doi.org/10.2466/06.11.16.PMS.115.4.325-335

Bekiari, A. (2014). Verbal Aggressiveness and Leadership Style of Sports Instructors and their Relationship with Athletes' Intrinsic Motivation. Creative Education, 5, 114-121. https://doi.org/10.4236/ce.2014.52018

Bekiari, A. (2016). Insights into Instructors' Verbal Aggressiveness and Students' Machiavellianism through Leadership Style and Motivational Climate. European Scientific Journal, 12, 90-110. https://doi.org/10.19044/esj.2016.v12n25p90

Bekiari, A. (2017a). Exploring Relations between Instructors' Verbal Aggressiveness and Argumentativeness and Students' Fair Play Behaviours and Machiavellianism. International Journal of Physical Education, 54, 26-39.

Bekiari, A. (2017b). Verbally Aggressive Instructors and Machiavellian Students: Is the Socio-Communicative Style an Over-Bridging? Psychology, 8, 1437-1454. https://doi.org/10.4236/psych.2017.810095

Bekiari, A., \& Balla, K. (2017). Instructors and Students Relations: Argumentativeness, Leadership and Goal Orientations. Open Journal of Social Sciences, 5, 128-143. https://doi.org/10.4236/jss.2017.57009

Bekiari, A., \& Hasanagas, N. (2015). Verbal Aggressiveness Exploration through Complete Social Network Analysis: Using Physical Education Students' Class as an Illustration. International Journal of Social Science Studies, 3, 30-49.

https://doi.org/10.11114/ijsss.v3i3.729 
Bekiari, A., \& Hasanagas, N. (2016a). Sociological Insights in the Education System: "Unlocking” the Power Relations. Thessaloniki: Afoi Kyriakidi Editions S.A.

Bekiari, A., \& Hasanagas, N. (2016b). "Educating" in Physical Education. Theoretical Approaches and Practical Inquiries. Thessaloniki: Afoi Kyriakidi Editions S.A.

Bekiari, A., \& Hasanagas, N. (2016c). Suggesting Indicators of Superficiality and Purity in Verbal Aggressiveness. An Application in Adult Education Class Networks of Prisoners. Open Journal of Social Sciences, 4, 279-292. https://doi.org/10.4236/jss.2016.43035

Bekiari, A., \& Manoli, P. (2016). EFL Teacher Verbal Aggressiveness and Argumentativeness and Student Socio-Affective Strategy Use and Affective Learning: Exploring Possible Associations. Journal of Teacher Education and Educators, 5, 154-171.

Bekiari, A., \& Pachi, V. (2017). Insights into Bullying and Verbal Aggressiveness through Social Network Analysis. Journal of Computer and Communications, 5, 79-101. https://doi.org/10.4236/jcc.2017.59006

Bekiari, A., \& Petanidis, D. (2016). Exploring Teachers' Verbal Aggressiveness through Interpersonal Attraction and Students' Intrinsic Motivation. Open Journal of Social Sciences, 4, 72-85. https://doi.org/10.4236/jss.2016.412007

Bekiari, A., \& Pylarinou, M. (2017). Instructor Argumentativeness and Socio-Communicative Style and Student Discipline: Using Physical Education Students' Class as an Illustration. Open Journal of Social Sciences, 5, 122-136. https://doi.org/10.4236/jss.2017.53011

Bekiari, A., \& Sakellariou, K. (2003). Perceived Instructor Verbal Aggressiveness and Student State Learning in Physical Education. Italian Journal of Sport Sciences, 1, 251-256.

Bekiari, A., \& Spanou, K. (2018). Machiavellianism in Universities: Perceiving Exploitation in Student Networks. Social Networking, 7, 19-31. https://doi.org/10.4236/sn.2018.71002

Bekiari, A., \& Spyropoulou, S. (2016). Exploration of Verbal Aggressiveness and Interpersonal Attraction through Social Network Analysis: Using University Physical Education Class as an Illustration. Open Journal of Social Sciences, 4, 145-155. https://doi.org/10.4236/jss.2016.46016

Bekiari, A., \& Syrmpas, I. (2015). Coaches' Verbal Aggressiveness and Motivational Climate as Predictors of Athletes' Satisfaction. British Journal of Education, Society \& Behavioural Science, 9, 318-329. https://doi.org/10.9734/BJESBS/2015/17757

Bekiari, A., Deliligka, S., \& Hasanagas, N. (2017). Analysing Networks of Verbal Aggressiveness and Motivation. Psychology, 8, 495-515.

https://doi.org/10.4236/psych.2017.83031

Bekiari, A., Deliligka, S., \& Koustelios, A. (2016). Examining Relations of Aggressive Communication in Social Networks. Social Networking, 6, 38-52. https://doi.org/10.4236/sn.2017.61003

Bekiari, A., Digelidis, N., \& Sakellariou, K. (2006). Perceived Verbal Aggressiveness of Coaches in Volleyball and Basketball: A Preliminary Study. Perceptual and Motor Skills, 103, 526-530. https://doi.org/10.2466/pms.103.2.526-530

Bekiari, A., Kokaridas, D., \& Sakellariou, K. (2005). Verbal Aggressiveness of Physical Education Teachers and Students' Self-Reports of Behaviour. Psychological Reports, 96, 493-498. https://doi.org/10.2466/pr0.96.2.493-498

Bekiari, A., Kokaridas, D., \& Sakellariou, K. (2006). Associations of Students' Self-Reports of Their Teacher's Verbal Aggression, Intrinsic Motivation, and Perceptions of Reasons for Discipline in Greek Physical Education Classes. Psychological Reports, 98, 451-461. https://doi.org/10.2466/pr0.98.2.451-461 
Bekiari, A., Koustelios, A., \& Sakellariou, K. (2000). Instructors' Verbal Aggressiveness from Universities in Greece. Studi e Ricerche, 5, 225-232.

Bekiari, A., Nikolaidou, Z., \& Hasanagas, N. (2017). Typology of Motivation and Aggression on the Basis of Social Network Variables: Examples of Complementary and Nested Behavioral Types through Conventional Statistics. Social Networking, 6, 135-147. https://doi.org/10.4236/sn.2017.62008

Bekiari, A., Pachi, V., \& Hasanagas, N. (2017). Investigating Bullying Determinants and Typologies with Social Network Analysis. Journal of Computer and Communications, 5, 11-27. https://doi.org/10.4236/jcc.2017.57002

Bekiari, A., Patsiaouras, A., Kokaridas, D., \& Sakellariou, K. (2006). Verbal Aggressiveness and State Anxiety of Volleyball Players and Coaches. Psychological Reports, 99, 630-634. https://doi.org/10.2466/pr0.99.2.630-634

Bekiari, A., Hasanagas, N., Theoharis, D., Kefalas, I., \& Vasilou, A. (2015). The Role of Mathematical Object and the Educational Environment to Students' Interpersonal Relationships: An Application of Full Social Network Analysis. In Proceedings of the 32nd Congress Greek Mathematical Society (with International Participation) (pp. 799-812). Kastoria.

Belias, D., \& Koustelios, A. (2014). Organizational Culture and Job Satisfaction: A Review. International Review of Management and Marketing, 4, 132.

Bennie, A., \& O'Connor, D. (2012). Coach-Athlete Relationships: A Qualitative Study of Professional Sport Teams in Australia. International Journal of Sport and Health Science, 10, 58-64. https://doi.org/10.5432/ijshs.201208

Bray, S. R., Millen, J. A., Eidsness, J., \& Leuzinger, C. (2005). The Effects of Leadership Style and Exercise Program Choreography on Enjoyment and Intentions to Exercise. Psychology of Sport and Exercise, 6, 415-425. https://doi.org/10.1016/j.psychsport.2004.07.003

Burroughs, W. J. (2005). Climate Change in Prehistory: The End of the Reign of Chaos. Cambridge: Cambridge University Press. https://doi.org/10.1017/CBO9780511535826

Chang, K., \& Chelladurai, P. (1997). Determinants of Quality in Fitness/Health Services: A Systems Approach. In 5th Annual Congress of the European Association for Sport Management. Glasgow, Scotland.

Chatzisarantis, N. L., \& Hagger, M. S. (2009). Effects of an Intervention Based on Self-Determination Theory on Self-Reported Leisure-Time Physical Activity Participation. Psychology and Health, 24, 29-48. https://doi.org/10.1080/08870440701809533

Chelladurai, P. (1978). A Multidimensional Model of Leadership. Unpublished Doctoral Dissertation, Ontario, CA: University of Waterloo.

Chelladurai, P. (1990). Leadership in Sports: A Review. International Journal of Sport Psychology, 21, 328-354.

Chelladurai, P., \& Carron, A. V. (1983). Athletic Maturity and Preferred Leadership. Journal of Sport Psychology, 5, 371-380. https://doi.org/10.1123/jsp.5.4.371

Chelladurai, P., \& Saleh, S. D. (1980). Dimensions of Leader Behavior in Sports: Development of a Leadership Scale. Journal of Sport Psychology, 2, 34-45. https://doi.org/10.1123/jsp.2.1.34

De Jong, J. P., \& Den Hartog, D. N. (2007). How Leaders Influence Employees' Innovative Behaviour. European Journal of Innovation Management, 10, 41-64. https://doi.org/10.1108/14601060710720546

Deliligka, S., Bekiari, A., \& Syrmpas, I. (2017). Verbal Aggressiveness and Argumentativeness in Physical Education: Perceptions of Teachers and Students in Qualitative and 
Quantitative Exploration. Psychology, 8, 1693-1717. https://doi.org/10.4236/psych.2017.811112

Donnelly, P., Carron, A. V., \& Chelladurai, P. (1978). Group Cohesion and Sport. Canadian Association for Health, Physical Education and Recreation.

Driver, R., Newton, P., \& Osborne, J. (2000). Establishing the Norms of Scientific Argumentation in Classrooms. Science Education, 84, 287-312. https://doi.org/10.1002/(SICI)1098-237X(200005)84:3<287::AID-SCE1>3.0.CO;2-A

Edwards, C., \& Myers, S. A. (2007). Perceived Instructor Credibility as a Function of Instructor Aggressive Communication. Communication Research Reports, 24, 47-53. https://doi.org/10.1080/08824090601128141

Goodboy, A. K., \& Myers, S. A. (2012). Instructional Dissent as an Expression of Students' Verbal Aggressiveness and Argumentativeness Traits. Communication Education, 61, 448-458. https://doi.org/10.1080/03634523.2012.699635

Gorden, W. I., Infante, D. A., \& Graham, E. E. (1988). Corporate Conditions Conducive to Employee Voice: A Subordinate Perspective. Employee Responsibilities and Rights Journal, 1, 101-111. https://doi.org/10.1007/BF01385039

Gouldner, A. W. (1960). The Norm of Reciprocity: A Preliminary Statement. American Sociological Review, 25, 161-178. https://doi.org/10.2307/2092623

Hamilton, M., \& Hample, D. (2011). Testing Hierarchical Models of Argumentativeness and Verbal Aggressiveness. Communication Methods and Measures, 5, 250-273. https://doi.org/10.1080/19312458.2011.596991

Hampson, R., \& Jowett, S. (2014). Effects of Coach Leadership and Coach-Athlete Relationship on Collective Efficacy. Scandinavian Journal of Medicine \& Science in Sports, 24, 454-460. https://doi.org/10.1111/j.1600-0838.2012.01527.x

Hasanagas, N., \& Bekiari, A. (2015). Depicting Determinants and Effects of Intimacy and Verbal Aggressiveness Target through Social Network Analysis. Sociology Mind, 5, 162-175. https://doi.org/10.4236/sm.2015.53015

Hasanagas, N., \& Bekiari, A. (2017). An Exploration of the Relation between Hunting and Aggressiveness: Using Inmates Networks at Prison Secondary School as an Illustration. Social Networking, 6, 19-37. https://doi.org/10.4236/sn.2017.61002

Hasanagas, N., Bekiari, A., \& Vasilos, P. (2017). Friendliness to Animals and Verbal Aggressiveness to People: Using Prison Inmates Education Networks as an Illustration. Social Networking, 6, 224-238. https://doi.org/10.4236/sn.2017.63015

Hassandra, M., Bekiari, A., \& Sakellariou, K. (2007). Physical Education Teacher's Verbal Aggression and Student's Fair Play Behaviors. The Physical Educator, 64, 94-101.

Hatton, C., Emerson, E., Rivers, M., Mason, H., Swarbrick, R., Mason, L., Alborz, A. et al. (2001). Factors Associated with Intended Staff Turnover and Job Search Behaviour in Services for People with Intellectual Disability. Journal of Intellectual Disability Research, 45, 258-270. https://doi.org/10.1046/j.1365-2788.2001.00321.x

Infante, D. A. (1981). Trait Argumentativeness as a Predictor of Communicative Behavior Insituations Requiring Argument. Central States Speech Journal, 32, 265-272. https://doi.org/10.1080/10510978109368105

Infante, D. A. (1987). Aggressiveness. In J. C. McCroskey, \& J. A. Daly (Eds.), Personality and Interpersonal Communication (pp. 157-192). Newbury Park, CA: Sage.

Infante, D. A., \& Gorden, W. I. (1989). Argumentativeness and Affirming Communicator Style as Predictors of Satisfaction/Dissatisfaction with Subordinates. Communication Quarterly, 37, 81-90. https://doi.org/10.1080/01463378909385529

Infante, D. A., \& Rancer, A. S. (1996). Argumentativeness and Verbal Aggressiveness: A 
Review of Recent Theory and Research. Communication Yearbook, 19, 319-351.

Kline, S. L. (1998). Influence Opportunities and the Development of Argumentation Competencies in Childhood. Argumentation, 12, 367-386. https://doi.org/10.1023/A:1007780507894

Koustelios, A. D. (2001). Personal Characteristics and Job Satisfaction of Greek Teachers. International Journal of Educational Management, 15, 354-358. https://doi.org/10.1108/EUM0000000005931

Koustelios, A. D., \& Bagiatis, K. (1997). The Employee Satisfaction Inventory (ESI): Development of a Scale to Measure Satisfaction of Greek Employees. Educational and Psychological Measurement, 57, 469-476. https://doi.org/10.1177/0013164497057003008

Koustelios, A., \& Kousteliou, I. (2001). Job Satisfaction and Job Burnout in the Education. Psychology, 8, 30-39.

Koustelios, A., Theodorakis, N., \& Goulimaris, D. (2004). Role Ambiguity, Role Conflict and Job Satisfaction among Physical Education Teachers in Greece. International Journal of Educational Management, 18, 87-92. https://doi.org/10.1108/09513540410522216

Kuhn, D., \& Crowell, A. (2011). Dialogic Argumentation as a Vehicle for Developing Young Adolescents' Thinking. Psychological Science, 22, 545-552. https://doi.org/10.1177/0956797611402512

Locke, E. A. (1999). The Essence of Leadership: The Four Keys to Leading Successfully. Lexington Books.

Lussier, R. N., Say, K., \& Corman, J. (1999). Improving Job Satisfaction of Employees Who Are Deaf and Hearing. American Journal of Business, 14, 69-73. https://doi.org/10.1108/19355181199900007

Luthans, F., Norman, S., \& Hughes, L. (2006). Authentic Leadership. In R. Burke, \& C. Cooper (Eds.), Inspiring Leaders (pp. 84-104). London: Routledge, Taylor \& Francis.

Manoli, P., \& Bekiari, A. (2015). EFL Teachers' Verbal Aggressiveness and Students' Intrinsic Motivation and Social-Affective Strategy Use: Investigating Possible Relations. Advances in Research, 5, 1-13. https://doi.org/10.9734/AIR/2015/19692

Monemi, S. T., \& Moghaddam, A. (2013). The Relationship between Leadership Style and Competitive Anxiety of Female Athletes. International Journal of Sport Studies, 3, 1387-1392.

Murray, M. P. (2006). Avoiding Invalid Instruments and Coping with Weak Instruments. The Journal of Economic Perspectives, 20, 111-132.

http://www.jstor.org/stable/30033686 https://doi.org/10.1257/jep.20.4.111

Myers, S. A. (2002). Perceived Aggressive Instructor Communication and Student State Motivation, Learning and Satisfaction. Communication Reports, 15, 113-121. https://doi.org/10.1080/08934210209367758

Myers, S. A., \& Claus, C. J. (2012). The Relationship between Students' Motives to Communicate with Their Instructors and Classroom Environment. Communication Quarterly, 60, 386-402. https://doi.org/10.1080/01463373.2012.688672

Myers, S. A., \& Knox, R. L. (2000). Perceived Instructor Argumentativeness and Verbal Aggressiveness and Student Outcomes. Communication Research Reports, 17, 299-309. https://doi.org/10.1080/08824090009388777

Myers, S. A., \& Rocca, K. A. (2000). The Relationship between Perceived Instructor Communicator Style, Argumentativeness and Verbal Aggressiveness. Communication 
Research Reports, 17, 1-12. https://doi.org/10.1080/08824090009388745

Myers, S. A., \& Rocca, K. A. (2001). Perceived Instructor Argumentativeness and Verbal Aggressiveness in the College Classroom: Effects on Student Perceptions of Climate, Apprehension and State Motivation. Western Journal of Communication, 65, 113-137. https://doi.org/10.1080/10570310109374696

Osborne, J. (2010). Arguing to Learn in Science: The Role of Collaborative, Critical Discourse. Science, 328, 463-466. https://doi.org/10.1126/science.1183944

Rancer, A. S., \& Avtgis, T. A. (2006). Argumentative and Aggressive Communication: Theory, Research and Application. Thousand Oaks, CA: Sage.

Rancer, A. S., \& Avtgis, T. A. (2014). Argumentative and Aggressive Communication: Theory, Research and Application (2nd ed.). New York, NY: Peter Lang.

Rancer, A. S., \& Infante, D. A. (1985). Relations between Motivation to Argue and the Argumentativeness of Adversaries. Communication Quarterly, 33, 209-218. https://doi.org/10.1080/01463378509369599

Rancer, A. S., Avtgis, T. A., Kosberg, R. L., \& Whitecap, V. G. (2000). A Longitudinal Assessment of Trait Argumentativeness and Verbal Aggressiveness between Seventh and Eighth Grades. Communication Education, 49, 114-119. https://doi.org/10.1080/03634520009379197

Rancer, A. S., Kosberg, R. L., \& Baukus, R. A. (1992). Beliefs about Arguing Predictors of Trait Argumentativeness: Implications for Training in Argument and Conflict Management. Communication Education, 41, 375-387. https://doi.org/10.1080/03634529209378899

Robbins, S. P., \& Judge, T. A. (2013). Organizational Behavior (15th ed.). Boston: Pearson.

Schmuck, R. A. (1968). Helping Teachers Improve Classroom Group Processes. The Journal of Applied Behavioral Science, 4, 401-435. https://doi.org/10.1177/002188636800400402

Schrodt, P. (2003). Students' Appraisals of Instructors as a Function of Students' Perceptions of Instructors' Aggressive Communication. Communication Education, 52, 106-121. https://doi.org/10.1080/03634520302468

Smith, M., \& Bourke, S. (1992). Teacher Stress: Examining a Model Based on Context, Workload, and Satisfaction. Teaching and Teacher Education, 8, 31-46. https://doi.org/10.1016/0742-051X(92)90038-5

Snyder, J. (1993). Myths of Empire (pp. 10-13). Ithaca, NY: Cornell University Press.

Somech, A. (2005). Teachers' Personal and Team Empowerment and Their Relations to Organizational Outcomes: Contradictory or Compatible Constructs? Educational Administration Quarterly, 41, 237-266. https://doi.org/10.1177/0013161X04269592

Storey, M. A. (2005). Theories, Methods and Tools in Program Comprehension: Past, Present and Future. In 13th International Workshop on Program Comprehension (pp. 181-191). New York, NY: Institute of Electrical and Electronics Engineers. https://doi.org/10.1109/WPC.2005.38

Surujlal, J., \& Dhurup, M. (2012). Athlete Preference of Coach's Leadership Style: Sport Management. African Journal for Physical Health Education, Recreation and Dance, 18, 111-121. http://hdl.handle.net/10520/EJC119845

Syrmpas, I., \& Bekiari, A. (2015). The Relationship between Perceived Physical Education Teacher's Verbal Aggressiveness and Argumentativeness with Students' Interpersonal Attraction. Inquiries in Sport \& Physical Education, 13, 21-32.

Theoharis, D., \& Bekiari, A. (2017). Applying Social Network Indicators in the Analysis of 
Verbal Aggressiveness at the School. Journal of Computer and Communications, 5, 169-181. https://doi.org/10.4236/jcc.2017.57015

Theoharis, D., Bekiari, A., \& Koustelios, A. (2017). Exploration of Determinants of Verbal Aggressiveness and Leadership through Network Analysis and Conventional Statistics. Using School Class as an Illustration. Sociology Mind, 7, 27-43. https://doi.org/10.4236/sm.2017.72003

Tremblay, R. E. (2000). The Development of Aggressive Behaviour during Childhood: What Have We Learned in the Past Century? International Journal of Behavioral Development, 24, 129-141. https://doi.org/10.1080/016502500383232

Tsigilis, N., Koustelios, A., \& Togia, A. (2004). Multivariate Relationship and Discriminant Validity between Job Satisfaction and Burnout. Journal of Managerial Psychology, 19, 666-675. https://doi.org/10.1108/02683940410559365

Vroom, V. H. (1964). Work and Motivation. New York, NY: John Wiley.

Weiss, H. M., \& Cropanzano, R. (1996). Affective Events Theory: A Theoretical Discussion of the Structure, Causes and Consequences of Affective Experiences at Work. In B. M. Staw, \& L. L. Cummings (Eds.), Research in Organizational Behavior: An Annual Series of Analytical Essays and Critical Reviews (Vol. 18, pp. 1-74). US: Elsevier Science/JAI Press. 